\title{
INTENDENCIA, JUSTICIA Y GOBIERNO: LA REAL CÉDULA DE 5 DE MARZO DE 1760 ¿NUEVO TRIUNFO DEL ORDEN TRADICIONAL?
}

\author{
MARÍA LóPEz DÍAz \\ Universidade de Vigo
}

\begin{abstract}
RESumen. Este artículo reconsidera el significado de la Real Cédula de 5 de marzo de 1760 a la luz del conflicto de competencias que lo motivó. Trata sobre las atribuciones de los intendentes en asuntos de jurisdicción ordinaria y los problemas que suscita la aplicación de la Ordenanza de 1749 con las Audiencias y Chancillerías territoriales, especialmente en el reino de Galicia, foco del conflicto. Después de examinar las causas, el desarrollo y el desenlace del proceso, con su trasfondo constitucional, valora el alcance jurídico de la medida. Asimismo, su relevancia política como precedente del decreto de 1766 que separa Intendencias y Corregimientos.
\end{abstract}

Palabras clave: Intendencia, Justicia/Gobierno, vía contenciosa, Fernando VI, España, Galicia.

\begin{abstract}
This paper reconsiders the meaning of the Real Cédula of March 5, 1760 from the conflict of competences that motivated it. It deals with the powers conferred on «intendentescorregidores» by the 1749 Ordinance in matters of ordinary jurisdiction, as well as the conflicts that its application raises with the territorial Audiences and Chancillerías. It deals particularly from the Kingdom of Galicia, which was the focus of the conflict. After examining the causes, development and resolution of the process, with its constitucional background, I assess the legal scope of the law. Likewise, I reconsider its political relevance as a precedent of the Royal Decree of 1766 that separates the Intendencias from the Corregimientos.
\end{abstract}

Keywords: Intendence, Justice/Government, process of law, Ferdinand VI, Spain, Galicia.

Recibido: 28-1-2020 • Aceptado: 4-3-2020 • marial@uvigo.es 
ES SOBRADAMENTE conocido que, tras más de un cuarto de siglo de lánguido discurrir, Ensenada restableció las Intendencias de provincia mediante la Instrucción de 13 de octubre de 1749 sobre la base de la ideada nueva contribución y otros muchos proyectos que puso en marcha ${ }^{1}$. El texto toma como modelo a su predecesora de $1718^{2}$, según el proemio, retocada con los cambios que la experiencia aconsejaba realizar, haciendo bueno de este modo el tópico común en la cultura jurisdiccional de la época de que la práctica mejoraba las «Leyes, estilos y Gobierno de una República» . En lo que atañe específicamente a los ámbitos de Justicia y de Policía, que son los que aquí nos interesan, clarifica ciertos puntos y lima el contenido «explosivo» de otros: aquellos que habían provocado más rechazo entre el mundo togado, coadyuvando a que en 1724 Felipe V extinguiera las Intendencias que no eran de guerra y rebajara las otras a «superintedencias agregadas a los corregimientos» (Kamen, 1964, p. 379). A estas rectificaciones todavía añadió otra novedad capital: la obligatoriedad del intendente «lego» de contar con asesores letrados en su labor judicial.

No me detengo a explicar los pormenores de todas y cada una de estas cuestiones, pues han sido objeto de otro artículo en el que cotejo las atribuciones judiciales de los intendentes en ambas ordenanzas, dando cuenta de las enmiendas que desactivaron las principales prerrogativas interventoras — vía sumaria - que les otorgaba la Ordenanza de 1718. Y es que en este asunto la monarquía, como tantas otras veces, acabó optando por una «adaptación sensata» que hiciera viable el proyecto (López Díaz, 2019). En dicho trabajo queda justificado también el interés de continuar investigando sobre el tema en el marco del revisionismo que se está llevando a cabo de los planteamientos racionalizadores y la reestructuración político-administrativa auspiciada por la Casa de Borbón en todos los ámbitos. En sentido amplio, se trataría de profundizar en el estudio de las atribuciones de los intendentes en las parcelas de Justicia y Gobierno político; o sea, en sus facultades en materia de jurisdicción ordinaria (Coronas González, 1998). Un asunto apenas explorado por la historiografía reciente, salvo excepciones (González Fuertes, 2010; ID., 2019; y desde perspectiva jurídica, Garriga, 2002a; ID., 2004; ID., 2007), lo mismo que ocurre con sus capacidades militares (Saavedra Vázquez, 2020), cuanto menos si se compara la producción existente sobre ambos cometidos con la nómina de trabajos que últimamente se han ocupado de su quehacer

Ordenanza de 13 de octubre de 1749 para el restablecimiento, è instrucción de Intendentes de provincias y exercitos, año 1749, Madrid, Imprenta de Manuel Fernández. Los 59 primeros capítulos pueden verse en Novísima Recopilación de las leyes de España (en adelante Novísima Recopilación), libro 7, título 11, ley 24 (en adelante se citarán solo las referencias numéricas siguiendo el mencionado orden); y los transcribe González Alonso, 1970, pp. 324-359.

2 Una vinculación sugerida por la historiografía, pero no probada. Véase, Anes, 1975, pp. 315 ss.; Ibáñez, 1986, p. 154.

3 Por ejemplo, el Memorial de 1707 del valenciano José Ortí, que reproduce Peset, 1972, pp. 694-713. 
en cuestiones de Hacienda y fiscalidad real (Dubet, 2011, pp. 103-105; ID., 2016; Dedieu, 2011, pp. 70-71; Muñoz Rodríguez, 2010, pp. 131-141; Gómez Gómez, 2004, pp. 203-251; Franch Benavent, 2014; Coll, 2015; etc.); un ramo desde el que algunos autores proponen incluso la aprehensión global del proyecto intendencial, por más que la hacienda fuera «sierva» de la guerra (Gómez Urdáñez, 1996).

Pues bien, en cierta forma este trabajo constituye una continuación de aquel, aunque el enfoque sea diverso. Atiende a la dimensión práctica de la mencionada Instrucción de 1749 o, más concretamente, a la actuación cotidiana del intendente en negocios de justicia y policía/gobierno en su doble faceta; es decir, como corregidorintendente de la capital y Corregimiento donde se asienta, y como intendente de la provincia. Geográficamente se contextualiza en el antiguo reino de Galicia, un territorio donde desde muy pronto surgen conflictos entre el intendente don José Avilés y la Real Audiencia, igual que con el resto de las autoridades del reino (Fernández Vega, 1982, vol. 2, pp. 347-357; Granados Loureda, 1987, pp. 122-126 y 131-149). En el primer caso, que es el objetivo central de este ensayo, hablamos de competencias jurisdiccionales que suscitaron «empeñados recursos» que acabaría resolviendo el rey una vez consultado el Consejo, y que motivaron la promulgación de dos nuevas disposiciones ${ }^{4}$ : una específica, dirigida al Real Tribunal, y otra de índole general, aplicable a todas las Intendencias - la R.C. de 5 de marzo de 1760-, cuya principal finalidad era subsanar algunas de las principales disfunciones del modelo.

A tenor de lo expuesto, y bajo las premisas de que «el derecho del Antiguo Régimen resultaba construido caso a caso mediante la tópica», que es la tarea de «encontrar»y «conciliar» universos normativos diversos (Garriga, 2006, p. 74), y de que la jurisprudencia de los Consejos mediante «la frecuencia de sus resoluciones forma la más genuina interpretación en las materias dudosas», en especial el Consejo de Castilla (Coronas González, 2010, p. 205) $)^{5}$, lo que propongo es reconsiderar el significado de la mencionada cédula a partir del expediente causante ${ }^{6}$. Añadiré alguna información complementaria procedente de otras fuentes, mayormente de las actas municipales de la ciudad de A Coruña, que es la capital de la Intendencia donde el intendente era también corregidor.

Antes de empezar conviene recordar que dicha real cédula es una conocida disposición, recopilada (Novísima Recopilación, libro 7, título 11, ley 24, notas 5 y 6) y

Para aligerar el texto usaré las siguientes abreviaturas al citar los distintos tipos de ordenamientos legales: Real Cédula (R.C.), Real Orden (R.O.), Real Decreto o Real Despacho (R.D.), Real Provisión (R.P.).

5 Según Campomanes, aquella es quien mejor podía ayudar a conocer e interpretar esta legislación, y con más autoridad y fuerza que la doctrina jurídica en sus distintos géneros. P. Rodríguez Campomanes, Tratado de regalía de amortización, Madrid, 1982, pp. 401 y ss.

$6 \quad$ Archivo Histórico Nacional (AHN), Consejos, 5977, exp. 39, s.f., y leg. 5977, s.f. (minuta). Es un extenso expediente de más de cuarenta folios (r. y v.) que no está foliado. De ahí que obvie referencias documentales, incluso haciendo citas textuales. 
coleccionada en El libro de las Leyes del siglo XVIII que ordena componer Campomanes ${ }^{7}$ - es significativo - , pero que asimismo referencian otros compiladores y juristas de la época ${ }^{8}$. También ha sido ampliamente citada por la bibliografía al uso, considerándola un antecedente inmediato de la R.C. de 13 de noviembre de 1766 — no se olvide, impulsada por Campomanes siendo fiscal del Consejo tras los motines de dicho año-, mediante la cual Carlos III separa formalmente Intendencias y Corregimientos y deslinda sus respectivos cometidos (Corona, 1980, p. 109; Gay Escoda, 1988, pp. 1644-1647). Más allá de esta constatación hay diversidad de opiniones respecto a su significado: desde quienes juzgan que sirvió para «clarificar» los poderes concedidos a los intendentes en la Instrucción de 1749 que resultaban dudosos o no estaban suficientemente delimitados en su labor como intendentes-corregidores - de ahí las pugnas con los tribunales ordinarios (González Alonso, 1970, p. 249) — hasta los que consideran que sencillamente redujo poderes al intendente en materia de jurisdicción ordinaria (Corona, 1980, p. 113; Pérez Martín, 1987, p. 167; Estrada Sánchez, 2003, pp. 218-219).

Son interpretaciones efectuadas a partir de la letra de la ley. Mi intención es hacer una relectura desde el análisis del proceso que la motiva. Esto permitirá, primero, conocer mejor a los actores locales, los motivos de competencia y el contexto institucional donde se gesta. Igualmente, dar cuenta de los argumentos jurídicos que fundan la actuación de cada cual, así como ahondar en las dos concepciones políticas enfrentadas que continúan existiendo en la práctica del gobierno en justicia casi cuarenta años después de la primera instrucción intendencial (Ibáñez Molina, 1986; Kamen, 1964, pp. 378-379; González Fuertes, 2003; Dubet, 2011, pp. 123-125), y que la unión de corregimientos e intendencias no solventó, subrayando, en última instancia, su trasfondo constitucional. Por último, calibrar el alcance jurídico-político de la decisión tomada sin perder de vista los representantes del rey, instituciones y agentes consultados.

\section{Un proceso decisivo en la Intendencia de Galicia}

En 1746 don José Avilés Itúrbide (1683-1767) es nombrado intendente de ejército del Reino de Galicia, asumiendo además los corregimientos de A Coruña y Baiona. Dicho nombramiento se produce después de una dilatada carrera militar que, según su

El libro de las leyes del siglo XVIII: Colección de impresos legales y otros papeles del Consejo de Castilla (1708-1781), edición a cargo de Santos M. Coronas González, Madrid, Boletín Oficial del Estado, 1996-2003, vols. 1-7, esp. II (1749-1766), libro V, pp. 1002-1003.

8 Por ejemplo, Sánchez Santos, Extracto puntual de todas las Pragmáticas, Cédulas, Provisiones y Autos Acordados publicados... Carlos III, Madrid, Imprenta de la Viuda e Hijo de Marín, 1792-1793, 3 vols., esp. I, p. 1; y de los segundos, F. Gallardo Fernández, Prontuario de las facultades y obligaciones de los intendentes, subdelegados, contadores, administradores, tesoreros y demás empleados en la administración y recaudo de las rentas reales, Madrid, Imprenta Real, 1806, capítulo II, artículo 87, p. 39. 
abultada hoja de servicios, comienza en 1700 y se vio favorecida por haber participado en la contienda sucesoria en distintos frentes (Franch Benavent, 2002, pp. 266-270). A partir de 1727 empieza a simultanear «empleos políticos», siendo su primer destino el de corregidor de Vich y gobernador militar de su partido. En 1743 asciende al rango de brigadier de dragones y este mismo año sería designado intendente de Saboya. Tres años más tarde es promovido a la Intendencia de Galicia, un puesto que entonces servía interinamente el comisario ordenador Pedro de Oarrichena y Borda (Granados Loureda, 1986, p. 317) $)^{9}$. Avilés presenta el título ante el ayuntamiento herculino y toma posesión del corregimiento el 2 de abril del citado año ${ }^{10}$. Según su propia valoración, como en su empleo anterior y los dos posteriores -intendente de ejército del Reino de Valencia y corregidor de la ciudad a partir de 1758, e intendente del ejército del Reino de Aragón, unido también al corregimiento de la capital, desde 1763 hasta 1766-, con notables logros en la labor realizada. De hecho, se atribuye, entre otros, mejoras en la recaudación de rentas reales, la organización de levas, el abastecimiento o el urbanismo; también la recuperación de bienes y de rentas del Real Patrimonio, así como el perfeccionamiento de la administración de la hacienda municipal de la capital. Una carrera de servicios de más de sesenta años que se verá recompensada con los títulos de vizconde de San Miguel y I marqués de Avilés, ambos concedidos por sendos despachos regios de 2 de abril de 1761 (Franch Benavent, 2002, pp. 270-273).

Esto es lo que figura en su haber, sus méritos. Pero su trayectoria profesional también proyecta sombras. Hablo de las irregularidades detectadas en su gestión —en el caso valenciano motivo de una pesquisa y subsiguiente traslado a la Intendencia aragonesa-; su carácter autoritario, que le granjeó no pocos conflictos y enfrentamientos con las autoridades territoriales en sus destinos «políticos» ${ }^{11}$, y la animadversión que suscitó en algunas poblaciones, tal y como se puso de manifiesto en el motín de Zaragoza de 1766 cuando los sublevados le obligaron a huir de la ciudad. De aquí regresaría a Madrid, donde tuvo que defenderse ante el Consejo del pliego de cargos que presentaron los cinco «cuerpos» de aquella ciudad en contra de su gestión (Franch Benavent, 2002, pp. 273-285; Corona, 1980, pp. 99-116).

$9 \quad$ Ejerció desde el 24 de septiembre de 1743 hasta el 1 de abril de 1746, tras el fallecimiento del titular del cargo Francisco Salvador de Pineda, quien antes fuera intendente de Valencia. Durante su mandato (años 1730) este también fue acusado de corrupción y objeto de diversos escritos satíricos del pueblo como su sucesor (Franch, 2002, p. 265).

10 Archivo Municipal de Coruña (AMC), Libro de Actas Acuerdos Capitulares (LAAC), LA de 1746 (C-46), CO 1/4/1746, ff. 107, 111-113v.

11 En Galicia, por ejemplo, tras conocerse sus quejas contra la Real Audiencia, en septiembre de 1757 fue llamado a la Corte, y apenas dos meses y medio después trasladado a la Intendencia de Valencia. AMC, $L A A C, L A$ de 1757 (C-53), CO 17/10/1757, ff. 87v-88, 117, 163-163v. Es la segunda vez que fue requerido por la Corte, pues ya lo había sido el 1 de enero de 1749 por cuestiones hacendísticas y de rentas reales. Archivo General de Simancas (AGS), SSH, leg. 0568, exp. 1, 7. 
Me interesa resaltar tres rasgos del personaje que considero determinantes, pues trenzan todo su currículum: uno es su condición de militar, con una carrera que corona como oficial de alta graduación y puestos políticos relevantes - siempre intendencias de ejército, las dos últimas de gran relevancia y similar categoría-; otro, su activa labor al servicio de la monarquía y la política regia; y el tercero, su talante enérgico, por veces irreverente, que le lleva a enfrentarse con los poderes e instituciones de los territorios donde desempeñó cargos. En este último aspecto coinciden los informes y las representaciones que procedentes de sus tres últimos destinos llegan a la corte, igual que en la intensa actividad que desarrolló o la singularidad de su etapa como intendente ${ }^{12}$. Galicia y la ciudad herculina, que figuran entre sus primeras ocupaciones políticas — primera de larga duración-, no sería menos.

Aquí, desde el mismo momento de su llegada, como sus predecesores, tuvo enfrente a tres de los principales poderes del reino: el gobernador-capitán general en lo militar, la Real Audiencia en lo judicial, y las ciudades y Junta del Reino (élites urbanas) en lo político, particularmente en materia de fiscalidad. Había otros, como el poder señorial o el poder eclesiástico — a la cabeza de ambos, por número de vasallos y como metropolitano, el arzobispo compostelano-, mermado el primero y muy debilitado el segundo por la política borbónica de signo contrario a sus privilegios (López Díaz, 2015, pp. 371-376). Desde 1726, a las dos primeras instituciones hay que añadir en lo civil el regente de la Audiencia, que coexiste con el gobernador. Este sigue siendo el presidente del real tribunal y la máxima autoridad militar, pero en asuntos de gobierno regente y gobernador tenían el mismo cometido, lo que provoca numerosas fricciones. Esta dualidad gobernador-regente se mantuvo hasta el año 1742, en que se decreta un cierto deslinde de sus cometidos, otorgándole al regente la primacía en lo judicial o técnico. De este modo el primero continúa dando las órdenes, aunque en negocios de «gobierno político» no podía resolver sin consultar previamente con el regente o decano, quien, a su vez, debía informar a la Audiencia (Fernández Vega, 1982, vol. 1, pp. 190-198) ${ }^{13}$. La Audiencia, por su parte, era inescindiblemente un órgano de gobierno - Real Acuerdo — además de un tribunal de justicia, que poseía unas amplísimas atribuciones que abarcaban los cuatro ramos de guerra, hacienda, justicia y gobierno. El problema: en ella, como en el resto de las instituciones de la monarquía absoluta, no se había alcanzado una satisfactoria diferenciación de materias, ni una correcta atribución a órganos especializados, máxime tratándose de los ámbitos de justicia y de

12 Es significativo que en los tres casos esos conflictos jurisdiccionales originan disposiciones de trascendencia (Corona, 1980, p. 109).

13 Hace referencia también a esta queja que elevó el conde de Itre, gobernador del Reino, al Consejo por los problemas de ceremonial y competencias que ocasionaba la dualidad gobernador-regente, la Real Audiencia en su réplica a las denuncias efectuadas por Avilés en el proceso estudiado. AHN, Consejos, 5977, exp. 39, s.f. 
gobierno. Como órgano jurisdiccional conocía de las apelaciones de todas las justicias del reino, incluidas las señoriales, pero también tenía jurisdicción civil y criminal en primera instancia en su lugar de residencia — desde finales del Xvi lo es la ciudad de A Coruña - con cinco leguas alrededor, y ello aunque las causas estuvieran pendientes ante los jueces ordinarios, así como de los denominados «casos de Corte» de todo el reino (Fernández Vega, 1982, vol. 1, pp. 128-131, 253-259).

En este contexto, los choques entre la Audiencia y el nuevo magistrado eran inevitables por las desmedidas atribuciones que acumulaba el segundo. Un cometido que, no se olvide, reordenaba el espacio político del reino y le recortaba facultades a aquella, pero también a las élites locales y demás autoridades que administraban justicia en el territorio (Granados Loureda, 1986, pp. 155-256). Añádase a ello la peculiar personalidad de José Avilés: de carácter dominante, pero gran celo profesional en el servicio a la Corona, que le lleva a defender con tesón las atribuciones inherentes a su cargo (comisarial), sacando a veces partido de sus considerables funciones. E igualmente, el reducido círculo de colaboradores de que solía rodearse. Todo lo cual ayuda a explicar que su mandato, tal y como sucedió en sus otros destinos, estuviera salpicado de tensiones, acusaciones más o menos graves y conflictos con los poderes, instituciones y cuerpos establecidos, empezando por el gobernador y la Audiencia de Galicia, que fueron los principales damnificados en lo gubernativo-judicial por su llegada, al ser aquel corregidor de A Coruña, sede de ambas instituciones, además de intendente del reino. Precisamente el expediente objeto de análisis y las disposiciones derivadas son un punto y seguido en esta secuencia de hostilidades.

\section{a) La pugna Avilés-Audiencia: colisión de competencias}

El origen del proceso está en dos representaciones elevadas por el intendente Avilés a la Corte en las que da cuenta de tres competencias con dicho tribunal, fechadas las dos primeras el 15 de noviembre y 6 de diciembre de 1756 y la tercera el 16 de julio de 1757. En ellas acusa a la Audiencia de perturbar su jurisdicción, arrogándose el conocimiento de causas que no le competían. En concreto, menciona los incidentes acaecidos los días 3, 4 y 11 del mes de octubre pasado, cuando estando los tres negocios «fundidos en su origen» viéndose en el Juzgado de la Intendencia, quiso volver a entrometerse igual que hiciera el 7 de agosto de 1751 con la fábrica de una casa propia de don Diego Cornide, vecino y abogado de la ciudad. En su caso, considerándolo un negocio «político, económico y gubernativo», el intendente había mandado suspender la obra, pero el afectado apeló a la Audiencia y esta solicitó los autos de la causa a dicho juzgado, presumiendo le correspondían las alzadas como tribunal superior por las leyes del reino y el artículo 1 de la Ordenanza de 1749. Avilés se negó, aduciendo que, aunque el asunto había sucedido en la ciudad donde era corregidor, no confundía 
sus prerrogativas al respecto con las de intendente del reino; ítem más — añade — que el Real Tribunal se afincara allí no le autorizaba para entrometerse en su jurisdicción como tal, que era «con la que había obrado», por ser privativo «el conocimiento de las matherias políticas y gubernativas del intendente» sin deber subordinación a la Audiencia, en tanto que los recursos debían ir directamente al Consejo. Todos estos autos, junto con las alegaciones de ambas instituciones, fueron remitidos al monarca por la vía reservada. Vistos, seguramente con parecer de Ensenada, Fernando VI resolvió que la Audiencia «no embarazase» las providencias dadas por el intendente suspendiendo la obra, por adecuarse a las reales ordenanzas y leyes del reino, y que tampoco lo hiciese en materias similares. Además, dispuso que si los interesados pretendían lo contrario acudiesen al Juzgado del Intendente, que era a quien tocaba el conocimiento «sin intervención alguna de la Audiencia», y que los recursos de sus decisiones se presentaran solo ante el Consejo (R.O. de 1 de octubre de 1751).

Señalaba Avilés que así lo había observado dicho tribunal hasta los «escandalosos» sucesos acaecidos en los tres casos denunciados. El primero tocante a una casa habitaba por doña María Isabel Piñeiro en la calle de Alfatería, principal de A Coruña, colindante con otra de don José Paredes y don Antonio Paredes, cuyo medianil amenazaba con derrumbarse; de ahí que en enero de 1755 hubiera acudido al Juzgado del Intendente, solicitando por oficio de gobierno que, en aplicación del artículo 32 de la Ordenanza ${ }^{14}$, dicha pared fuera reconocida por peritos y se obligara a los susodichos a arreglarla a su costa. Notificada la demanda, Antonio Cotón se opuso, aduciendo que no era dueño absoluto de la misma y, fundándose en una escritura de partijas que condicionaba a los causantes del referido José Paredes a comprar a los de Cotón su pequeña porción, pidió que este lo hiciera (por tasación presente) o bien le vendiera su parte para construir en el terreno de ambas una casa ostentosa lindante a dicho frontispicio. Una vez oídas sumariamente las partes y después de haber convenido Paredes vender su porción a Cotón, ordenó el intendente que este fabricase la casa ofrecida y pagase los más de 200 reales que le costara a María Isabel apuntalar la pared de la suya mientras no se construía un nuevo medianil. Cotón pidió ciertos cambios en la ejecución del abono, pero Avilés, de conformidad con su asesor letrado, los rechazó. Así es que la parte contraria solicita la retención de autos y apelación del fallo para la Audiencia, suponiendo que aquel había procedido como corregidor de la ciudad. El Juzgado del Intendente admitió su apelación como «asunto político», pero no para el Real Tribunal sino para el Consejo según lo dispuesto en la R.O. de 1751. Reacción fulgurante la del ministro semanero de la Audiencia, quien también la admite, requiriendo al «escribano de gobierno» del

$14 \quad$ Manda a los intendentes «se esmeren en el cuidado de la limpieza, ornato, y empedrados de las Ciudades, Villas y Lugares de la Provincia», Ordenanza de 13 octubre de 1749, Índice, s.f., y artículo desarrollado, f. 13. 
intendente los autos. Y como no los entrega, le apremia. Para evitar más disturbios Avilés ordena remitirlos, reservándose el derecho a informar al rey de tan «inauditos y estraños echos practicados por la Audiencia», con los que — recuerda — se falta a la «correspondencia y armonía» que preceptuaban las resoluciones reales.

Así lo hizo, según consta en la primera representación que remitió al Consejo. En el escrito da cuenta también de otro altercado con la Audiencia ocurrido a finales de 1755. Este se incoó el 4 de noviembre con una petición presentada ante el intendente por don Santiago Fernández Rochel, administrador de la renta del tabaco en el partido de Foxo de Deza (jurisdicción de Deza, provincia de Pontevedra). Expone que por allí pasaba la vereda y el camino real que enlazaba Santiago con Ourense y otras partes, que transitaban las tropas reales y un gran número de personas; y, lo más importante, que en sus términos nacía una fuente abierta que ganados y personas solían enturbiar haciéndola inservible, razones por las cuales solicita permiso para encañarla a su costa dándole otros usos. A mayores pedía el auxilio de la justicia ordinaria para ejecutar una obra que, alegaba, interesa a la «utilidad pública». El intendente libró la providencia pedida y Rochel construyó dicha cañería rompiendo para ello algunas propiedades particulares, sobre todo la de don Juan García Regueiro, quien sintiéndose agraviado recurrió ante el intendente por el perjuicio que le ocasionaba la obra y al público al privarles del uso del agua tanto a él como a otros dueños de tierras. Pidió que se recibiese información e hiciese visita ocular, así como el diseño de la obra por peritos para probar que fuera realizada con «dolo y cautela». A la vista de la reclamación, Avilés, de conformidad con su asesor, mandó a Rochel deshacer la cañería y el pilón que había construido cerca de su casa para el agua, volviendo las cosas al estado inicial; también le condenó al pago de costas (junio 1756). Como en el caso anterior, al serle notificado el auto, el afectado solicitó la inhibición del juzgado intendencial y que la causa fuese remitida al juez ordinario de Deza, apelando de lo contrario. Avilés admite la alzada, pero para el Consejo y solo con efecto devolutivo, no en el suspensivo, debiendo por tanto ejecutarse su providencia. También aquí el demandante apela a la Audiencia, que la admite y apremia al escribano intendencial a entregar los autos.

Concluye el intendente su representación reiterando que ambos asuntos eran de tipo «político, económico y gubernativo» como el de la casa de Cornide; que su conocimiento correspondía al Juzgado Intendencial y que las apelaciones, según la disposición de 1751, debían ir al Consejo, pues intervino como intendente y no como corregidor. Finalmente, acusa al tribunal gallego y a sus oficiales de abuso de poder, en tanto que ensalza el trabajo efectuado por sus predecesores en el cargo. Al respecto, recuerda la importancia que había tenido la aplicación de los primeros cuarenta y nueve artículos de la Instrucción para la «utilidad pública» del reino, y de la ciudad herculina en particular, pues en pocos años había mejorado sensiblemente su apariencia 
gracias a su quehacer (edificios, empedrado, limpieza de calles, etc.). Por el contrario, desdeña la actuación de la Audiencia con frases lapidarias («nada visible havía echo»), le acusa de actuar violentamente recurriendo al brazo militar, así como de injerirse en sus procesos y no observar las ritualidades de los tribunales ni las formalidades del «despacho exhortatorio con el tratamiento que [le] correspondía» como comisario regio. Incluso se arroga una calculada superioridad jurisdiccional, señalando que:

no dexaría también de ser mui propio de su Justicia suplir y enmedar los procedimientos de aquella Audiencia, maiormente quando todos los suios no tenían otro objeto que el amor, y seguir con toda su aplicación y celo la voluntad de V. Mgd y acertadas reglas establecidas en sus ordenanzas.

Son palabras que evidencian la alta estima en que Avilés tenía su cargo y las tareas encomendadas, y también la tirantez existente entre ambas instituciones. Lo corrobora en el otrosí final del escrito: pide que se mande a la Audiencia respetar «la buena correspondencia y armonía que acostumbraba [haber] entre tribunales de dibersas jurisdicciones en los casos contenziosos» y cumplir las disposiciones regias.

No era menos inculpatoria la segunda representación que remite al Consejo. En ella daba cuenta de otra competencia de índole gubernativa, acusando de nuevo al Real Tribunal de entrometerse a conocer de las alzadas. El proceso comienza cuando los vecinos del lugar de Facós (feligresía de San Vicente de Lobeira, provincia de Ourense) acuden al intendente solicitando que les permita aprovechar el agua de un arroyo abandonado para fertilizar sus tierras, a lo que se oponen los de otros tres lugares colindantes (Vilachá, Quintas y Bergontias, actual Bergoncias de la misma jurisdicción). Pero el intendente, tras los reconocimientos pertinentes, resuelve a favor de los primeros amparándose en el artículo 25 de la Instrucción de $1749^{15}$. Descontentos, Miguel González y otros parroquianos de las segundas apelan a la Audiencia. Y esta, como en los casos anteriores, reclama los autos con apremio militar. Avilés sube el tono de sus acusaciones, calificando su proceder como «otro atentado por el sonido del corregidor», que a decir del procurador de la parte recurrente eran «las puertas (sic) por donde venían los encuentros y las facultades que se tomaba» aquella.

Idénticas imputaciones hace contra el fiscal de la Audiencia: teniendo a su cargo «celar» las leyes reales, las quebrantaba y pasaba por encima de las ordenanzas regias, las de su Consejo y otras similares dadas por las Audiencias y Chancillerías. Termina su escrito acusando al tribunal gallego y a su fiscal de usar métodos irregulares en contra de la Intendencia «como si fuera un juez pedáneo [o sea, sin jurisdicción ejecutiva]

15 «Que se fertilicen los Campos con nuevos regadíos, sacando Acequias de los Rios y descubriendo las aguas subterraneas, para facilitar la abundancia de frutos, y el aumento de Molinos, Batanes, y otras maquinas», Ordenanza de 13 octubre de 1749, Índice, s.f., y artículo desarrollado, ff. 10-11. 
o le fuera dependiente y subordinado» en su actuación; añadiendo, con altanería, que esperaba por todo lo dicho y lo que por «su acostumbrada modestia» callaba merecer el amparo del Consejo para cumplir su cometido en lo judicial-gubernativo.

Con sus representaciones Avilés remitió al Consejo una copia de la mencionada R.O. de 1 de octubre de 1751 . No en vano era el principal sustento legal, junto con la Instrucción, de su actuación en las tres causas.

b) Los fundamentos de hecho de la Audiencia: la primacía de la vía «consiliar»

A la vista de tales denuncias, el Consejo pide a la Audiencia que justifique su proceder y alegue en su defensa. Esta responde con un extenso escrito, cuajado de ironía y animadversión hacia el intendente. Empieza criticando su insolencia y el tono desconsiderado que emplea no solo al referirse al real tribunal sino también con el Consejo, atribuyéndolo al «acaloramiento» que le hacía perder las formas. A continuación, rebate su exposición de los hechos y también sus principales argumentaciones. Así, por un lado, lo acusa de considerarse juez privativo de cuanto obraba en los cuatro ramos, amparándose en la Ordenanza, sin más subordinación que la debida al Consejo (de Castilla) y a los Consejos de Guerra y Hacienda, obviando de este modo el derecho de la Audiencia a conocer en dichas causas. Por otro, de suponer, sin fundamento alguno, que esta utilizaba su condición de corregidor de la ciudad para admitir las alzadas de sus providencias. No negaba que fuera el intendente del reino y de su ejército, pero ambos empleos — prosigue - según el artículo 68 de la Ordenanza de 1718 y 73 de la de 1749 , tenían inspecciones diferentes ${ }^{16}$. De hecho, precisa, cuando procedía como corregidor en la capital y su término, en lo civil y criminal, en asuntos de gobierno político y policía, aquella era tribunal superior, no teniendo el intendente «arbitrio para resolver ni executar cosa alguna» sin informarle previamente para que determine (Instrucción de 1718, artículo 66 ${ }^{17}$ ), concluyendo que si Avilés hubiera leído con atención dicho capítulo en el $1^{\circ}$ de su homónima de 1749 «no fatigaría la atenzion del Consejo» con insinuaciones falsas. También contradice su repetido razonamien-

16 «Quando fuere Intendente de Exercito, estará á su cargo la subsistencia, y policía de él, excepto lo que es peculiar á los Directores, é Inspectores», Ordenanza de 4 de julio de 1718 para el establecimiento, e instrucción de Intendentes... Madrid, Imprenta de Juan de Aritzia, 1720, f. 74; «A cargo de los Intendentes, que fueren de Exército, estará la subsistencia, y Policía de él, excepto lo que es particular de los Inspectores, ó Directores; reducido el cuidado de los Intendentes en la subsistencia, á Sueldos, y Viveres», Ordenanza de 13 de octubre 1749, Índice, s.f., y artículo desarrollado, ff. 26-27.

17 «Estarán á su orden los Corregidores; y en caso de encargarsele este empleo en la ciudad de su residencia, lo servirá con la misma subordinacion que los demás Corregidores», Ordenanza de 4 de julio de 1718 para el establecimiento, e instrucción de Intendentes..., Índice, s.f., y artículo desarrollado, f. 72. 
to de que cuando actuaba en «lo político y gubernativo» procedía como intendente, aconsejándole no mostrarse tan ufano con «su grande y celosa vigilancia» en el reino. Al respecto invoca sus facultades en materia de pobres y vagabundos, así como las correspondientes instrucciones, en la última de las cuales el rey ordenaba que los intendentes-corregidores ejerciesen su comisión en el corregimiento acumulativamente con los alcaldes mayores del reino ${ }^{18}$. Igualmente, le acusa de usar su doble condición de corregidor e intendente y la confusión que ocasionaba el desempeño de ambos oficios, pretendiendo sin embargo conocer de todo tipo de dependencias en concepto de intendente, considerando que por «este artificio se libraba de la indecorosidad que comprendía sería a su tamaño y carácter subordinación a la Audiencia».

En la segunda parte de su alegación, la Audiencia da su versión sobre lo ocurrido en cada caso. Del primero dice que el intendente hizo un relato exagerado. Lo reduce a que, en noviembre de 1753, la mencionada María Isabel Varela otorgó poder a procurador de la Audiencia para que apremiase a los dueños de la casa contigua a la suya a abonar parte de los gastos de reparación de la pared medianil; y este acudió al Real Tribunal, mientras la parte contraria lo hizo al intendente (enero de 1754), quien remitió la causa a su asesor. Añade que el proceso estuvo en dicho juzgado hasta septiembre de 1756, apostillando que tal era «el breve expediente que tenían los pleitos en el Juzgado del Intendente». Fue entonces cuando la demandante apeló a la Audiencia de su providencia, quien pidió primero y apremió después al escribano del intendente por negarse a entregar los autos; de ahí su intervención y diligencias posteriores. Tales fueron, señala, los «escandalosos echos» denunciados por Avilés, al tiempo que delata las calumnias que vierte en su escrito contra la Audiencia y sus ministros con acusaciones falsas, impropias del abolengo de su cargo. También llama la atención sobre lo ajenas que eran las pretensiones de las partes del cometido del artículo 32 de la Instrucción de Intendentes en el que el susodicho sustentaba su actuación, pues la única pretensión de la demandante era que los dueños de las casas contiguas contribuyesen a arreglar la pared medianil, no el ornato o reedificación de su fachada. En su opinión, esto probaba que la vulneración era premeditada: siendo un caso de justicia ordinaria urbana (corregidor), no procedía que interviniera el Juzgado del Intendente ni tampoco su asesor («subdelegado») salvo como alcalde mayor.

18 Carta circular del año 1746 a los corregidores y cabezas de partidos, encargándoles la aprehensión de ociosos y vagamundos de que se debía hacer el remplazo del ejército, en El libro de las leyes del siglo XVIII..., edición de Santos M. Coronas González, 1996, vol. 1, libro III, pp. 594-595; véase también la Ordenanza de 13 octubre de 1749, capítulos 21 y 22 (Novísima Recopilación, 12, 31,14). Por disposición de 25 de julio de 1751 se extiende dicha facultad a las justicias ordinarias. A este respecto, véase Respuesta del fiscal Lópe de Sierra, de 30 de julio de 1763, en Coronas González, 1992, pp. 314-318; asimismo, la Real Ordenanza de 7 mayo 1775 para las levas anuales (Novísima Recopilación, 12, 31, 7). 
Igualmente cuestiona su relato de los hechos en el caso Rochel contra García Rigueiro por la canalización del agua de aprovechamiento público-privado. Alega que bastaba cotejarlo con el recurso de apelación presentado por el primero en contra de la resolución del intendente para ver lo ajena que era su pretensión del artículo 25 de la Ordenanza en que se amparara Avilés para intervenir, pues la disputa era sobre el derecho de particulares a usar el agua. Y, colige, aunque no tuviera facultades para conocer la Audiencia de la apelación — cosa que no niega, reconociendo indirectamente que pudo haberse extralimitado - aquel no debería haberla admitido para el Consejo por evitar gastos a las partes.

Del mismo tenor son sus justificaciones en la tercera causa — vecinos de Facós con los de Vilachá y feligresías colindantes_-, iniciada el 25 de mayo de 1754 con la demanda interpuesta por los primeros ante la Intendencia, que contradicen los segundos. Especifica que también intervino su asesor, aunque el Juzgado de la Intendencia no despachó auto definitivo hasta dos años después. Fue entonces cuando los primeros apelaron a la Real Audiencia, que consultó la admisión del recurso al fiscal; y tras responderle afirmativamente, en noviembre, reclamó la entrega de los autos. Completa su alegato volviendo a acusar a Avilés de prepotencia y abuso de poder, a la par que criticaba la desmedida autoridad otorgada al nuevo agente local, la unión de Intendencias y Corregimientos y la confusión que provocaba el desempeño de funciones por uno y otro concepto. Nada excepcional, pues otros tribunales superiores del territorio peninsular estaban haciendo lo mismo (Vallejo García-Hevia, 2008, pp. 141-145).

Como acusaciones particulares, le reprochaba su habilidad y la de su asesor para propiciar largos y costosos litigios, amén de su exacerbado «celo y aplicación al bien público» hasta el punto de acusar al mismo fiscal, un servidor del rey (Coronas González, 1992, pp. 37-41; Fernández, 1982, I, pp. 121-123). Lo achacaba a su vivo genio, que le lleva a «lastimar a quantos no apoiaban sus ideas». También censura la tan cacareada brevedad de que hacía gala en sus representaciones frente a la lentitud que atribuía a la Audiencia, apostillando que no le sorprendía, por ser «enfermedad embejezida un argos, el más observado, para ver la arista en el ojo ajeno». Bastaba observar el curso de los tres casos denunciados en el tribunal del intendente; añadiendo, con evidente socarronería, que se excusarían gastos y perjuicios a los naturales del reino si el susodicho estuviera informado y hubiese potenciado la ejecución del mapa geográfico, tal y como ordenaba la Instrucción (capítulos 19 y 20) para participárselo al rey y sus tribunales, en vez de mandar abrir nuevas acequias para hacer regadíos.

Otro juicio de valor atañía al citado artículo 25, a la sombra del cual pretendía conocer en todos los procesos tocantes al uso del agua: aunque el intendente tuviera facultades para hacer contenciosas estas causas en su juzgado — asuntos de gobierno que devienen judiciales-, cuestiona el modo en el que ejerció dicha jurisdicción en 
el pleito de Rochel, pues «las aguas sobre que se havían subzitado no eran rios para sangrarlos por las partes más conbenientes»; y aun pudiendo hacerlo sería sin perjudicar a terceros y respetando siempre su derecho a apelar en juicio. Lo mismo cabía decir considerando la naturaleza de las causas: si juzga contenciosamente - o sea, con asesoría letrada - negocios de «gobierno y polizia» —lato sensu, lo gubernativo, político y económico - , las alzadas competían a la Audiencia. Así fuera desde el establecimiento de dicho tribunal en 1480, según las Reales Ordenanzas, cédulas, visitas y disposiciones varias, agregando que de esta jurisdicción pretendía Avilés «desnudarla para bestirsela como intendente de provincia», presuponiendo que por la Instrucción de 1749 el rey la había depositado en su instancia con subordinación solo al Consejo. Lo corroboraba el decreto a la queja que el marqués de Croix, gobernador del Reino, planteó al Consejo en su pugna con el regente, disponiendo que en asuntos de gobierno político no providenciase sin informar a la Audiencia a través del regente (R.O. de 20 de febrero de 1748). A su juicio, probaba que la intención de Fernando VI no había sido privar a dicho tribunal de la jurisdicción gubernativa y política que ejercía junto con el gobernador desde hacía dos siglos. Y tampoco lo hizo con la mencionada Ordenanza de 1749 , pues como intendentes en lo judicial no tenían más facultades que «estimular a las justicias a observar en sus pueblos y ciudades las reglas de buen gobierno» (artículo 32). Tanto más cuanto en asuntos de justicia y gobierno no disponían de conocimiento privativo como en Hacienda y Guerra o en lo tocante a la fábrica de paños.

Sobre la R.O. de 1 de octubre de 1751, que califica como «ancora del intendente», recuerda lo estipulado en los capítulos 66 de la Instrucción de 1718 y $7^{\circ}$ de la de 1749, que aquel obviaba al vetar las apelaciones a la Audiencia, pues mientras que el primero señalaba que donde tenía encomendado el corregimiento de la capital debía desempeñarlo con igual subordinación que el resto de corregidores, por el segundo ( $\left.\mathrm{y} \mathrm{n}^{\mathrm{o}} 38\right)$ estaba obligado a observar los Capítulos de Corregidores de 1648. También contradice su interpretación del artículo $1^{\circ}$ de la Ordenanza ensenadina, aduciendo que si bien le otorgaba atribuciones en los cuatro ramos, era con subordinación a los tribunales superiores según la tipología de las causas. Esto evidenciaba que el rey no pretendía confundir o alterar las jurisdicciones, ni menos privar a la Audiencia gallega y demás tribunales superiores de provincia del conocimiento gubernativo y político. Lo confirmaba el introito de la Instrucción al reconocer que había sido elaborada siguiendo el modelo de la de 1718, rectificando lo que la práctica hizo aconsejable. La lectura del órgano colegiado a este respecto es clara: equivale a decir, respetando las leyes del reino y sin alterar el orden judicial establecido, aunque hoy sabemos que en dicho «retoque» hubo más razones; la principal hacerla «digerible» para el mundo togado (López Díaz, 2019).

Abunda la Audiencia en sus argumentos dando cuenta de lo ocurrido en otras tres causas de «justicia política, gobierno y economía» que tuvieron lugar entre los 
años 1752 y 1756 . Habiendo Avilés aceptado las alzadas de las partes para el Consejo de Castilla, este sin embargo desestimó las apelaciones y mandó remitirlas al tribunal gallego por el menor coste para los demandantes ${ }^{19}$, desautorizando así la forma de proceder de aquel. Además, probaba que con la R.O. de 1751 el rey no buscaba:

dar lo que con tanta ansia solicitaba el Intendente, maiormente quando en matherias de la maior delicadeza havía sido uno de los principales motivos para que los tribunales reales inmediatos o respectivos exerciesen la regia protectiba, $\mathrm{y}$ económica potestad, alzando las violenzias, y desaziendo los atentados cometidos contra los vasallos de S. Magd. ${ }^{20}$.

Y añadía que si lograba su propósito perjudicaría a los naturales y pobres del reino al ponerles el remedio de sus causas lejos del mismo.

Termina señalando que este tipo de disputas se cortarían de raíz y se evitarían gastos a los naturales si el rey y su Consejo mandasen al intendente proceder como corregidor en lo gubernativo, económico y de policía de la ciudad y su corregimiento, y que las providencias que adoptase o considerase que redundaban en beneficio público las comunicase como órgano gubernativo superior al Real Acuerdo, ejecutando sus decisiones. Respecto al distrito provincial, entiende que las debía transmitir a las justicias de los pueblos, villas y ciudades, y velar porque estos las aplicasen, sin admitir recursos, pues tocaban al Real Tribunal. También propone que se le ordenase no obstruir la jurisdicción gubernativa de la Audiencia y del gobernador, absteniéndose de conocer en su Juzgado sobre causas de gobierno político contenciosamente y permitiendo las alzadas — ya fuesen de agravio o en apelación — para la Audiencia. Y respecto al lenguaje que emplea en los despachos y autos que remite, importante desde el punto de vista simbólico pero también práctico (poder de mando), pide que observe las formalidades establecidas y que no emplee el voseo en sentido ofensivo ${ }^{21}$ so grave pena, ni tampoco otros vocablos de dominación.

$19 \quad 1^{\circ}$ ) Resolución del Consejo de 29 de mayo de 1752 sobre la apelación interpuesta por vecinos de los partidos de San Clodio y Cuñas contra providencia del intendente. $2^{\circ}$ ) Ídem de la ciudad de Santiago sobre providencia gubernativa dada por la justicia (quitar canalones de las calles) y la que a instancia de don José Fole de Navia había avocado el intendente a su Juzgado, mandando por Real Auto de 17 de febrero de 1756 se abstuviese de continuar en el procedimiento. $3^{\circ}$ ) Ídem resolución del Consejo de 11 de septiembre de 1754 a vista de apelación de don Manuel Tomás Fernández, vecino Pontevedra, de los procedimientos del intendente sobre paga de cantidades de maravedíes para el abasto de carne, mandando acuda a la Audiencia. AHN, Consejos, 5977, exp. 39, s.f.

20 La cursiva es mía. La «regia protectiva» hace referencia a la jurisdicción protectiva y eminente del soberano. Véase, Vallejo García-Hevia, 1996-1997, p. 295.

21 Pronombre de tratamiento Vos entendido en sentido peyorativo de superior a inferior por razón de autoridad. 


\section{El valor de la consulta y dictamen del Consejo}

Una vez recibidas las alegaciones de la Audiencia de Galicia, el Consejo solicitó el preceptivo informe al fiscal (Cabrera Bosch, 1993, pp. 16-25, 52-56 y 65-74; Castro, 2015, pp. 269-272; Coronas González, 1992, pp. 37-49; Vallejo García-Hevia, 1996-1997, pp. 53-60). Desconozco a cuál de los dos fiscales tocó, pues en el mismo no consta su nombre. Se ha sugerido que pudo estar detrás Campomanes, pero por las fechas en que este accedió a la fiscalía del Consejo (1762) es imposible (Pérez Martín, 1987, p. 168). Quizás fuera el asturiano don Lope de Sierra Cienfuegos, colegial, caballero conocido y ministro desinteresado de sensibilidad diversa a aquel ${ }^{22}$, pues el otro fiscal del Consejo - Francisco de la Mata Linares - no consta en las salas de los años 1757 y 1760 (Castro, 2015, pp. 324-325) y la respuesta fiscal se evacuó el 13 de septiembre de $1758^{23}$. En cualquier caso, se trata de un escrito denso, concienzudo y de gran claridad expositiva. Las dos cédulas reales que propugnó hacen difícil sostener que fueran fruto de la improvisación o de la coyuntura política. Quien lo elaboró era consciente de la trascendencia del encargo: hablamos de un conflicto que venía a sumarse a otras denuncias llegadas al Consejo por la desmedida autoridad con la que procedían los nuevos intendentes-corregidores y sus continuas disputas con las Chancillerías y Audiencias de su circunscripción. Ciertamente, no era algo nuevo, pues lo mismo había sucedido a raíz de la Instrucción de 1718 (Giménez López y Pradells Nadal, 1989, pp. 592-596). Tal es así, que desde el primer momento el jurisconsulto identifica dos tipos de problemas: uno general, que afectaba a todos los intendentes —es, a saber, la «verdadera interpretación» de la arquitectura jurídica del Reglamento de 4 de julio de 1749 - ; y otro particular, que incumbía únicamente a la Audiencia e intendente gallegos, los dos comparecientes del proceso.

Comienza por el primero, exponiendo sus reflexiones sobre la Instrucción de 1749 mediante la cual Fernando VI restableció las Intendencias de provincia. Para el letrado estaba claramente dividida en tres partes y netamente diferenciados los cometidos del intendente, así como los tribunales donde debían ir los recursos. Por un lado, sitúa los negocios englobados en los cuarenta primeros capítulos, salvo el 23, que era de su conocimiento privativo ${ }^{24}$ : son todos materia de jurisdicción ordinaria

$22 \quad$ En 1766 será nombrado ministro de dicho Consejo (Gómez-Rivero, 1999, pp. 451 y 453 ). Sobre su linaje, véase Anes, 1995, pp. 3-21; de su enfrentamiento ideológico y jurídico con Campomanes, véase Coronas González, 1992, pp. 161-162; Molas, 2000, pp. 69-70. Para los casos donde intervino con Campomanes, Vallejo García-Hevia, 1997, pp. 178, 208 y ss., pp. 312-313, p. 331 y pp. 421-423; sobre el pensamiento jurídico-político del último, véase Álvarez de Morales, 1989.

23 De hecho, Concepción de Castro no ofrece información sobre la composición de las salas de los años 1758 y 1759, y en la de 1760 cita junto a Lope de Sierra Cienfuegos entre interrogantes a Juan Martín de Gamio.

24 «Fomentarán en los Pueblos capaces, y á propósito las Fábricas de paños, y demás Artes, y Oficios mecánicos», Ordenanza de 13 de octubre de 1749, Índice, s.f., y artículo desarrollado, f. 10. 
tocantes a «Gobierno, Policia y Justicia» por su naturaleza, y en ellos los intendentes intervienen en calidad de corregidores. Alega que donde solo había corregidores caso de Salamanca, Trujillo y otros pueblos - estos conocían por sí mismos, y donde la Intendencia y el Corregimiento estaban separados no lo hacía el intendente sino el corregidor; y en el resto el corregidor o el gobernador, como en Barcelona. Adviértase que agrupa los artículos de los ramos de Justicia y Policía, a los que añade los $n^{\circ}$ 1 (genérico) y 40 (primero de Hacienda) ${ }^{25}$, evidenciando la dificultad de separar las dependencias de justicia y gobierno político (López Díaz, 2019, pp. 577-580). En el segundo bloque de atribuciones coloca los asuntos de Hacienda y rentas reales, ámbito de una jurisdicción especial. Y el tercero correspondía a los de Guerra, concernientes a otra jurisdicción especial, el fuero castrense.

Fijadas las tres grandes esferas del cometido intendencial, el magistrado centra sus razonamientos en la primera, que es el escenario de las competencias objeto del dictamen. Entiende que los intendentes debían proceder conforme a las leyes e Instrucción de corregidores, con subordinación a las Audiencias y Chancillerías, que son los tribunales superiores a quienes correspondía conocer de los agravios y apelaciones de lo gubernativo de los pueblos. Como fundamentos de derecho cita la Nueva Recopilación (libro 2, título 5, leyes 53 y 54), las Ordenanzas de la Real Audiencia de Galicia (artículo 2), la Ordenanza de intendentes de 4 de julio de 1718 (artículo 66) y cuatro capítulos de la Instrucción de 13 de octubre 1749 (1, 7, 38 y 39). En concreto, sobre el 39, que ordenaba a los intendentes examinar y observar lo dispuesto en las leyes del reino para la buena administración de justicia, así como para el gobierno político y económico de los pueblos, considera que tenía continuidad en el siguiente; y que este avalaba su planteamiento, al declarar que lo antedicho era respectivo a «los negocios de Justicia y Gobierno Político, y Económico» que debían observar los intendentes-corregidores, concepto en su opinión equivalente al de corregidor. Y añade que la citada ordenanza les encomendaba que preservasen la paz en los pueblos y evitasen parcialidades, pasiones y venganzas, imponiendo su autoridad y pudiendo llamar a las justicias para apercibirlas de su obligación (artículo 9), pero —el matiz es importante — se trataba de una «superioridad económica, y gubernativa puramente», no jurisdiccional.

Incide en su razonamiento invocando el artículo 2 de la Ordenanza de 1718 que concedía amplias facultades a los intendentes en su provincia, incluida la de pedir los autos a las justicias, punto que fuera revocado por la Instrucción de 1749, capítulo 2 (López Díaz, 2019). De hecho, prevenía expresamente que en esta especie de pre-

25 El capítulo 1 motiva el restablecimiento de los intendentes y unión de Intendencia-Corregimiento de la capital, dando cuenta de su cometido en los cuatro ramos. Los 17 siguientes son específicos de Justicia; del 19 al 39 regulan sus atribuciones de Policía; los 29 siguientes las de Hacienda (el 40 las reglas prescriptas para este ámbito) y del 70 al 146 las de Guerra. 
ponderancia sobre las justicias ordinarias debían proceder los intendentes «por vía sumaria, económica o guvernatiba», indicando que sus facultades no eran extensivas a los pleitos y causas que «por su gravedad, interes, ó motibos (fuesen de oficio, o partes)» debían seguir su curso contenciosamente ante los tribunales. Pero, de manera elocuente, el fiscal no entra a valorar - tampoco lo hiciera la ley- a quien correspondía determinar la gravedad de las mismas, el interés o las razones por las que esos asuntos debían tramitarse por justicia, o sea, con trámite de audiencia, justificando así la intervención de las Audiencias en negocios de justicia y jurisdicción ordinaria en los que conocía el intendente fuera de su corregimiento. Reconoce, ciertamente, que esta competencia era clara a la vista de los capítulos 9 y 18 de la Instrucción de 1749, al disponer que no bastando con sus advertencias para contener a las justicias provinciales debían dar cuenta con justificación a los tribunales superiores pertinentes, y al rey de las «cosas graves que juzgaren dignas de su noticia», previniendo si lo hiciera a dichos tribunales. En su opinión, ello probaba que la superioridad de los intendentes en materia de justicia dentro de su distrito provincial:

no pasaba, ni devia pasar de [la] amonestación; las justificaciones del nudo echo y para dar quenta a las Audiencias y Chancillerías inmediatas, y a estas [correspondía], y nunca a los Intendentes, las providencias contenciosas en los negocios de Gobierno, Policia y Justicia ${ }^{26}$.

Concluye que no había diferencia alguna entre corregidores, intendentes de provincia e intendentes de ejército en tales negocios. Pues, igual que los intendentes tenían conocimiento privativo en los ramos de Hacienda y Guerra, no tendrían facultades en negocios de Justicia, Policía y Gobierno si no tuvieran acumulado el oficio de corregidor de la capital (artículo $1^{\circ}$ ); siendo así forzoso reconocer que en tales capítulos los intendentes procedían únicamente como corregidores y que los recursos de sus decisiones debían ir a los respectivos tribunales.

Como fundamentos jurídicos que avalan su planteamiento, el fiscal cita dos dictámenes del Consejo de Castilla. Uno en parte aducido por la Audiencia: la resolución a la queja elevada por la ciudad compostelana frente al recurso que en 1755 interpuso el canónigo don Pedro Fole de Nava ante el intendente, contradiciendo un bando de buen gobierno que publicó, en julio de 1754, la justicia municipal a pedimento de los verederos. El fallo del alto organismo fue claro: manda al intendente apartarse del recurso y remitir los autos a la Real Audiencia «donde tocaba», y que en adelante se abstuviera de conocer por este medio o en apelación — si la demanda se interponía ante

La cursiva es mía. «Nudo hecho» no existe como tal concepto jurídico actualmente ( $c f$. https://dej. rae.es/). Por semántica léxica con el de nuda propiedad vendría a significar un derecho «desnudo» de atribuciones, o sea, no de pleno dominio. 
las justicias ordinarias - de causas de «justicia, política, gobierno ó económica». Veredicto casi idéntico al que evacuó en los excesos denunciados por el conde de Oñate, como curador del marqués de Mondéjar, a instancias del alcalde mayor de Alconchel (en abril y junio de 1755), ante el rey; y también los representados por los alcaldes mayores de Alburquerque y Cáceres (en 1755 y 1756, respectivamente), en su caso ante el Consejo, acusando al intendente de Extremadura de injerirse a conocer y proceder en causas de justicia. También en estos litigios desaprobó las actuaciones intendenciales, apercibiendo a los respectivos titulares para que en adelante se ajustasen a la Ordenanza a la hora de admitir recursos voluntarios que perturbaban el ejercicio de la jurisdicción ordinaria. A mayores, el Consejo y fiscal consultados advierten al rey de que este tipo de competencias desviaban su atención de los negocios que eran verdaderamente graves y propios de su conocimiento, censurando la «perversa» interpretación que hacían los intendentes y las partes de los capítulos de la instrucción, infiriendo «que no se cortaría ni los intendentes se aquietarían si V. M. no lo declaraba». La crítica va implícita.

Para la fiscalía la solución al problema no era una cuestión de legalidad sino de voluntad política. De ahí su empeño en situarla en manos del soberano. Su propuesta al respecto es clara: que el rey disponga que todos los intendentes que tengan unido el corregimiento de la capital, ya procedieran en primera instancia y con jurisdicción ordinaria como corregidores (ciudad-capital y distrito corregimental) o bien como intendentes en su provincia con la autoridad o superioridad que les otorgaba la Ordenanza de 1749 sobre las justicias locales, en ambos casos las apelaciones de los asuntos tocantes a los cuarenta primeros capítulos, salvo el 23, y en cuanto fuese de justicia, gobierno político y económico, debían ir las Audiencias y Chancillerías inmediatas, según lo preceptuado en dicho reglamento, que en este punto concordaba con las leyes del reino.

Sobre las competencias de la Audiencia e intendente de Galicia en particular, considera que había un elemento añadido esencial: la R.O. de 1 de octubre de 1755 en que Avilés sustentaba sus denuncias. Las tres tratan de asuntos de policía y gobierno que concernían a los cuarenta primeros capítulos de la Instrucción: las causas de María Isabel Varela y de Rochel al artículo 25 y la tercera (vecinos de Facós) al 32. Por tanto, formalmente las partes habían acudido bien al intendente-corregidor y este había procedido correctamente admitiendo sus demandas, pero, según las leyes y el espíritu de la Ordenanza, lo hace con jurisdicciones o potestades diferentes: en el primer caso como corregidor, con solo la jurisdicción ordinaria (la demandante era vecina de A Coruña donde estaba su casa), y en los otros dos como intendente, con las atribuciones y superioridad económica que le otorgaba la disposición en la provincia, no debiendo confundirse ambos conceptos para el uso de jurisdicciones y legitimidad de los recursos. Como intendente, valiéndose de la jurisdicción política, económica y gubernativa que le confería la Instrucción en su distrito, pudo ciertamente proceder en las dos instancias. Pero las apelaciones de sus decisiones debían ir a la Audiencia tanto 
por las disposiciones generales (comprensivas en las leyes citadas 53 y 54) y artículos 1 y 9 de la Instrucción intendencial, como por las específicas del tribunal gallego (capítulo 2 de sus Ordenanzas) y leyes del reino «para lo universal»; las cuales, recuerda, no fueran derogadas por aquella, sino al contrario (capítulos 1 y 9). En un otrosí reconoce, sin embargo, que de esta regla general había quedado excluido el intendente gallego mediante la resolución regia de 1751, la cual también sacó los asuntos de «gobierno económico y político» de su curso regular, al disponer que «en obras que incumbían a la maior hermosura y otras semejantes» conociese sin intervención de la Audiencia y que los agraviados recurriesen directamente al Consejo. Igualmente constata que el titular del cargo, José Avilés, usaba esta disposición para conocer como intendente de todo lo gubernativo, económico, político y providencial, restringiendo al concepto de corregidor las dependencias contenciosas. De manera que todos los negocios tocantes a los 40 primeros artículos de la Instrucción solía juzgarlos como intendente y amparándose en la orden de 1751 negaba las apelaciones para la Audiencia.

En definitiva, considera que en las tres causas denunciadas el intendente había actuado correctamente y otorgado bien las alzadas para el Consejo, siendo improcedente la intervención de la Audiencia, incluida la apelación de la causa de María Isabel Varela. De sus descargos solo consideraba aceptables dos: uno, que de ir los recursos a dicho tribunal se evitarían gastos a las partes, aunque formalmente no debió haberse injerido en los procesos denunciados, sino «representar la bejazión haciendo merito del sacrificio»; y el otro, la provocación del lenguaje e inadecuadas expresiones, por veces hirientes, que empleaba Avilés en sus escritos al dirigirse a dicho tribunal de jurisdicción superior. Probaba, añadía, que las prevenciones del Consejo a raíz de su primera queja no habían servido para nada. En parte incluso justificaba las intromisiones de la Audiencia respondiendo a sus provocaciones, de la misma forma que consideraba inútil volver a apercibirle. Como en lo general, su propuesta era favorable al cuerpo togado: derogar la R.O. de 1 de octubre de 1751, restituyendo a la Audiencia el derecho a conocer en primera instancia y apelaciones de las resoluciones del intendente tocantes a los 40 primeros capítulos de la Instrucción, salvo el 23, así como las facultades gubernativas y judiciales que le reconocía el capítulo 2 de sus Ordenanzas, de las cuales fuera despojada; dicho de otra forma, eliminar el privilegio concedido al intendente gallego sobre lo dispuesto en la Instrucción general. Y en lo particular, solicitar los autos originales de las mencionadas causas para resolverlas, conminando a la Audiencia a no admitir recursos entre tanto.

Sus sugerencias tienen eco en el Consejo de Castilla. Reunida la Sala de Gobierno en sesión de 14 de junio de $1758^{27}$, a la que asisten los consejeros Cristóbal de Mon-

Según Castro, 2015, p. 52, hasta el siglo XVIII no cuaja la costumbre de dejar anotado en las consultas la sala de que proceden y el nombre de los consejeros presentes. En nuestro expediente consta la sala que publica la resolución (Gobierno) y la fecha. 
soriú, Diego Adorno, Manuel de Montoya y Zárate, Francisco de Cepeda y Manuel Ventura Figueroa, presididos por el gobernador, Diego de Rojas y Contreras, obispo de Calahorra y la Calzada ${ }^{28}$ — la mayoría manteístas, dos o tres incluso vinculados al «tomismo» oficial ${ }^{29}$ - en su dictamen el Consejo se conformó con el informe fiscal. De hecho, resume con precisión sus argumentos, realizando solo pequeñas matizaciones de redacción. En conjunto, pormenoriza los defectos del sistema intendencial y de la Instrucción de 1749, destacando cuatro aspectos: 1) la claridad de los cometidos y jurisdicciones que le otorgaba al nuevo magistrado, su diferenciación -incluidos los procedimientos y trámite de las alzadas - y la lesiva interpretación que hacía Avilés de algunos de sus artículos; 2) la indistinción de los asuntos de los ramos de Justicia y de Policía — que abarca Gobierno y Política -, concernientes unos y otros a la jurisdicción ordinaria, cuyos recursos y apelaciones debían ir a las Audiencias y Chancillerías correspondientes; 3 ) la perversa interpretación que hacía el intendente gallego considerando solo al Consejo como tribunal superior y negándole esta condición a la Audiencia, que tenía reconocida por las leyes, la Instrucción y ordenanzas de las audiencias; 4) las disfunciones orgánicas que provocaba la R.O. de 1751, que recortaba poder a dicho tribunal y propiciaba continuos conflictos con el intendente, quien se entrometía a conocer incluso en asuntos contenciosos, así como los problemas que ocasionaba a los naturales, con retrasos y sobrecostes en la resolución de sus causas. Concluye que, aun admitiendo que la Audiencia se había extralimitado en los casos juzgados, podía excusarse su proceder dada la conducta del oponente, quien, ávido de poder, se resistía a reconocerla y guardarle la subordinación debida, incluso cuando actuaba como corregidor o juez ordinario.

También suscribe las propuestas del ministerio fiscal para zanjar este tipo de enfrentamientos que pasaban por despachar dos disposiciones regias: una declarando con carácter general que, del mismo modo que los intendentes conocían privativamente en materias de Hacienda y Guerra y los recursos y apelaciones iban a los respectivos Consejos, también en los asuntos de Justicia y Policía — en sentido amplio «justicia, economía, policía y gobierno»— comprendidos en los 40 primeros capítulos de la Instrucción, salvo el 23, debían proceder únicamente como corregidores en su circuns-

28 Pueden no ser los titulares de dicha sala, pues esta a veces tomaba prestados consejeros de otras menos sobrecargadas. Sobre los trámites y forma de solventar los asuntos tras la reestructuración del Consejo, véase Cabrera Bosch, 1993, pp. 16-25 y 64-77; Castro, 2015, pp. 47-52 y 269-272.

29 Diego de Rojas es colegial de Oviedo y en 1760 será designado camarista. Monsoriu, Cepeda, Ventura Figueroa y Montoya eran manteístas: el primero y el último (que fuera huésped en el Colegio mayor de Santa Cruz de Valladolid) manteístas «thomistas»; el segundo era también colegial de Oviedo y el tercero jesuita profeso, veáse Gómez Rivero, 1999, pp. 434-435, 443, 440-441 y 443-444. Para visión general del reclutamiento y carrera de consejeros y fiscales, Gómez Rivero, 1999, pp. 427-431; Fayard, 1982, pp. 35-81. 
cripción, sin extender sus facultades a la provincia, y con la debida subordinación a los tribunales superiores de justicia; es decir, admitiendo los recursos para las Audiencias y Chancillerías de sus respectivas circunscripciones. Además, teniendo en cuenta las dudas que suscitaban las atribuciones que les otorgaba el capítulo 9 en los pueblos de su provincia, convendría precisar por otra orden regia que eran estrictamente gubernativas y económicas, para advertir o apercibir a las justicias locales, debiendo notificárselo a aquellas si no surtía efecto esa amonestación. Y con respecto a las competencias de la Audiencia e intendente gallegos, aunque recriminaba el proceder de la primera —en vez de transgredir la ley debía haber informado - invoca la benignidad del rey y defiende la conveniencia de revocar la R.O. de 1751, apercibiendo a Avilés para que en adelante tratara con respeto al dicho tribunal y moderase el vocabulario de sus escritos.

\section{La decisión regia: hacia una nueva visión del superior gobierno}

\section{a) La real cédula de 1760 y el orden establecido}

Evacuado el expediente el mismo 14 de junio de 1758, subió a consulta del monarca el 30 de agosto, en un momento crítico del reinado de Fernando VI: coincidiendo con su última enfermedad que minora el número de memoriales y consultas solicitadas, una situación que se agrava tras morir la reina Bárbara de Braganza a principios de agosto de 1758, inagurándose lo que algún autor denomina el «año sin rey», que concluye con el fallecimiento del monarca al siguiente (Gómez Urdáñez, 1996). Es por ello que hasta la llegada de su sucesor, a finales de 1759, no hay respuesta a las consultas del Consejo y resoluciones pendientes de publicación (Castro, 2015, p. 303). Tal sucede con la de nuestro expediente: sentencia Fernando VI, que sanciona el dictamen del Consejo, pero no se publica la decisión regia hasta el 30 de enero de 1760. En cuanto llega Carlos III manda despachar las dos cédulas pertinentes. Nada sorprendente, pues también se retoman algunos proyectos ensenadistas (Gómez Urdáñez, 1996, p. 122). En lo que aquí nos interesa, las mencionadas disposiciones — una dirigida a todos los intendentes-corregidores, que, anticipamos, fue recopilada; y la otra dirigida a la Real Audiencia de Galicia, ambas fechadas el 5 de marzo - no sufren ningún cambio. Con la primera se pretendían aclarar las facultades de los intendentes-corregidores en asuntos de Justicia y Policía (capital y término corregimental) y su separación práctica de las correspondientes en ambos ramos a su cometido como intendente de provincia; eso sí, sin descender en la distinción de las funciones de gobierno (económico) de las judiciales, salvo en lo procedimiental (vías institucionales). También incide en su obligación como jueces ordinarios de reconocer la superioridad de las Audiencias y Chancillerías competentes, debiendo admitir para ellas las alzadas: en el primer caso (materias de justicia) por la jerarquía contenciosa; en el segundo, la residencia era solo gubernativa, no entrando a valorar el encargo práctico del intendente en la materia que 
colisionaba con el de la Audiencia. La segunda cédula, remitida al regente del tribunal gallego, dejaba sin efecto la R.O. de 1 octubre de 1751 con las prevenciones señaladas.

Del análisis del expediente y las disposiciones derivadas llaman la atención, entre otras, tres cuestiones. En el plano del ordenamiento, el cambio operado en la forma de tramitar y sustanciar las competencias surgidas entre Avilés y la Audiencia entre principios y mediados de los años 1750: mientras que en la primera causa de la que tenemos información (casa de Cornide) aquel presentó su queja y obtuvo la mencionada R.O. de 1751 por la vía reservada, en las dos representaciones posteriores se sigue la vía consiliar (Consejo de Castilla) aunque por la gravedad del asunto que lo sustancia consultando el rey. También difieren las resoluciones: mientras el primero exonera al intendente de Galicia del vínculo orgánico con el tribunal superior competente, separándolo en punto a jurisdicción ordinaria de lo establecido en la Instrucción de 1749 a la par que le recorta competencias a aquel realzando la autoridad de Avilés, el segundo le derogará esa autonomía o singularidad formal; además, se incorporan aclaraciones sobre el cometido práctico de los intendentes-corregidores en asuntos de Justicia y Policía y el orden de los recursos. Llegamos así al tercer matiz, corolario de los anteriores: atañe a la funcionalidad y es de orden político. Dado que los intendentes-corregidores no solían deslindar los cauces diferenciados de la jurisdicción real ordinaria - justicia/gobierno, justicia/policía — por la indistinción orgánica que sigue existiendo (la institución intendencial es un ejemplo), multiplicándose los abusos de autoridad y conflictos con los tribunales jerárquicamente superiores, se comprende que, como solución, el cuerpo togado optase por reunificar en su entendimiento los negocios de justicia y gobierno a ellos encomendados en aquella jurisdicción (real ordinaria) que actuaban cotidianamente, añadiendo la coletilla de que esa tarea debían ejercerla con subordinación a las Audiencias y Chancillerías competentes. La pregunta parece obligada: ¿(nuevo) triunfo de los sectores judicialistas de la Monarquía, en particular del Consejo de Castilla y tribunales superiores, o sensata rectificación?

Es indudable que el conflicto de competencias de los intendentes-corregidores con las respectivas Audiencias y Chancillerías por las apelaciones de sus decisiones se resolvió en favor de la jurisdicción ordinaria por la R.C. de 5 de marzo de 1760 (Estrada Sánchez, 2003, p. 218), salvándose de la quema solo el artículo 23 (fomento de fábricas). Pero no es menos cierto que la reacción del aparato hacendístico, que contrapesa dicha disposición con medidas como el R.D. de 10 junio de 1760, que concedía a la Intendencia facultad privativa en el conocimiento de asuntos concernientes al Real Patrimonio, dejando malparadas las pretensiones de las Audiencias y Tribunales ordinarios, tras el conflicto de la Audiencia e intendente de Valencia (García Monerris, 1991, pp. 286-293); o también la creación un mes después, en julio de 1760, de la Contaduría General de Propios y Arbitrios que atribuía a los intendentes la fiscalización y control directo de las haciendas locales, amén de otras disposiciones específicas de la 
jurisdicción de los propios y arbitrios (García García, 1996, pp. 210-219), inician una etapa de «equilibrio» entre ambas magistraturas (Pérez Martín, 1987, pp. 166-171). Pero la explicación para una adecuada comprensión del tema es más compleja, pues la R.C. de 1766 que separa Intendencias y Corregimientos no deja de ser un episodio más de esa dialéctica entre dinámicas —a la hacendística debería añadirse también la militar-, efectivamente resuelta a favor del viejo «entramado polisinodial» (Fernández Albaladejo, 1992); y aquella un antecedente o parche para solventar los problemas derivados de una institución que acumula encargos tan dispares como los de la Intendencia y el Corregimiento (Vallejo García-Hevia, 2008, pp. 141-146). En este contexto, con avances y claros obstáculos al desarrollo de los aspectos modernizadores de una monarquía administrativa que se abre paso, como tendencia, en el XVIII, se comprende el conflicto aquí analizado y las dos resoluciones contrapuestas de 1751 y 1758-1760 que certifican las vacilaciones. Mientras en el primer caso se intuye la mano de Ensenada en la decisión de Fernando VI, que actúa con resabio «ministerial», en el expediente posterior el conflicto entre instituciones y/o esferas de poder lo resuelve el mismo rey, pero con su nuevo ministro, preservando el proyecto y tratando de eliminar sus defectos con cesiones al modelo jurisdiccional. De por medio está la caída del marqués y el cambio operado en el equipo de gobierno («segundo gobierno») de la monarquía que «desacelera» proyectos pasados por más que pervivan las directrices (Gómez Urdáñez, 2019, pp. 160-163).

$\mathrm{Y}$ en lo que atañe a Galicia es evidente también el giro: se limita la autoridad del intendente y devuelven facultades recortadas a la Real Audiencia, queriendo zanjar así las hostilidades y roces suscitados localmente por el experimento realizado en dicha provincia al puentear al tribunal territorial. Es una medida que combina pragmatismo y oportunidad, retornando al reino a la «uniformidad» de la Instrucción. Un dato elocuente: antes incluso de publicarse la resolución del expediente, el nuevo intendente Juan Felipe de Castaños, queriendo remediar «algunos abusos» hallados en la forma de gestionarse las dependencias judiciales en dicha Intendencia, promulga una interesante disposición, impresa y publicada en todo el reino, sobre los requisitos y trámites para litigar en dicho juzgado ${ }^{30}$. Invita a pensar que Avilés había ido demasiado lejos en su labor comisarial, apartándose de la jurisdicción ordinaria.

\section{b) ... Y una reflexión final}

En 1997, Vallejo García-Hevia, al reseñar la monografía de F. Abbad y D. Ozanam, Les Intendants espagnols du XVIII siècle (1992), hacía algunas precisiones a ciertas afirmaciones vertidas por los autores y otros estudiosos de la implantación

AMC, $L A A C, L A$ de 1759 (C-53), f. 84. 
de las intendencias a partir de su investigación. Alude a la insistencia con que solía interpretarse dicha reforma en el marco de las tensiones entre la tradicional vía consiliar (Consejos de Castilla y de Hacienda, sobre todo) y la naciente vía reservada (desplegada por las Secretarías de Estado y del Despacho de Guerra y Hacienda), responsabilizando al Consejo de Castilla y estado togado del fracaso de la Instrucción de 1718, así como de los progresivos retoques que sufrirá el sistema intendencial restablecido en 1749 (Vallejo García-Hevia, 1996-1997, pp. 547-557). Un hilo conductor que sigue estando presente en gran parte de las investigaciones recientes, incluidas las del ámbito hacendístico (Gómez Gómez, 2008; Dubet, 2016, o la colaboración de la mencionada Dubet en este monográfico). Para dicho autor, sin embargo, verificar solo este hecho o ceñir la explicación de dicha confrontación a una simple lucha de poder y de vías de tramitación de asuntos (que no se niega) entraña una «simplificación excesiva» para comprender la organización y el funcionamiento de la monarquía borbónica, proponiendo una interpretación más amplia que considere el sistema intendencial como parte del reformismo borbónico (Vallejo García-Hevia, 1996-1997, pp. 554-557); un reformismo que, efectivamente, durante la etapa carolina impulsa cambios o mejoras (no entro a valorar el cariz) en casi todos los ámbitos de poder, además del hacendístico y militar, que van desde la administración judicial y órganos centrales a la estructura municipal.

Concuerdo en parte con su planteamiento, que como hándicap pone el foco solo en dos de los tres flancos del modelo intendencial. Pero, por otro lado, va en la línea de lo que ya en su día sugirieron autores como Fernández Albaladejo (1992), con perspectiva política, o más recientemente, con enfoque jurídico, Carlos Garriga al tratar del reformismo borbónico o aspectos concretos del mismo: la paulatina administrativización del gobierno tanto en la corte como en el plano territorial, que es donde se producen los cambios más notables; o, si se prefiere, la lenta emergencia junto a la monarquía jurisdiccional de otra de tipo administrativo, la llamada «dinámica estatal» del siglo XVIII (Garriga, 2002a, pp. 781-821; ID., 2004, pp. 13-44; ID., 2008, pp. 106-110; ID., 2010, pp. 715-766). Simplificando muchísimo, se trataría de «reducir los espacios materialmente ocupados por la justicia e inevitablemente mediatizados por sus magistrados, y construir sobre la base de este modo 'liberada' otro aparato, cuyo eje había de ser el intendente»; un agente capacitado para desplegar actuaciones gubernativas, que opera con criterios administrativos, libres de la tutela judicial (Garriga, 2007). Otra cosa son los logros.

De trasfondo están los debates observables durante toda la centuria en torno a la Justicia, que en última instancia lo son en torno a culturas jurídicas, basadas en líneas de pensamiento muy distintas sobre lo que es Estado, Sociedad y Justicia. En el caso planteado, como hemos visto, subyace esa tensión latente entre la alta judicatura 
y la política. La disposición de 1760 tiene interés porque, con la separación que se establece para «el gobierno y policía de los pueblos» respecto a los otros dos ramos, se está anunciando la futura instrucción de corregidores que aún tardará seis años en llegar, la cual, además de separar Corregimientos e Intendencias, apunta una nueva idea que late de fondo: que los cargos civiles deben ejercerlos civiles-letrados, y no militares. Ciertamente, es una reforma concebida todavía en términos de justicia, pero usando la palanca del servicio (común utilidad de los vasallos del reino) y defensa de los intereses del rey y de su soberanía.

Así planteadas las cosas, la R.C. de 1760 no es tanto un triunfo del orden corporativo-letrado cuanto un perfeccionamiento o mejora del sistema, anticipatoria del decreto de 1766. Y este un paso adelante en la dicotomía gubernativo-contencioso para diferenciar autoridades (separación orgánica) en atención a su potestad (letrados/ militares), aunque no para deslindar materias ${ }^{31}$. Lo mismo sucederá con otros avances llevados a cabo en los años posteriores que culminan en las disposiciones aprobadas en 1783, que junto con las de 1788 y 1799 institucionalizan una «carrera de varas» —profesionalización - en la monarquía hispana (González Alonso, 1972, pp. 245-279; Gay Escoda, 1988, pp. 1647-1722; González Fuertes, 2019, pp. 234-245). Detrás hay concepciones políticas y una dialéctica que certifica su existencia en la que se combina reformismo con pragmatismo.

\section{AGRADECIMIENTOS}

Trabajo realizado dentro del Proyecto de Investigación HAR2017-83605-P, cofinanciado por la Agencia Estatal de Investigación (AEI) y el Fondo Europeo de Desarrollo Regional (FEDER, UE).

Aunque progresivo, el proceso será lento. Véase Garriga, 2002b; ID., 2010, pp. 320-321. 


\section{Bibliografía}

Álvarez de Morales, Antonio (1989), El pensamiento político y jurídico de Campomanes, Madrid, Instituto Nacional de Administración Pública.

Anes, Gonzalo (1975), El Antiguo Régimen: los Borbones, Madrid, Alianza Editorial.

ANEs, Lidia (1995), «Don Lope de Sierra Cienfuegos, fiscal del Consejo de Castilla en el reinado de Carlos III», Cuadernos de Estudios del siglo XVIII, 5, pp. 3-21.

Cabrera Bosch, María Isabel (1993), El Consejo Real de Castilla y la ley, Madrid, Consejo Superior de Investigaciones Científicas.

Castro, Concepción de (2015), El Consejo de Castilla en la historia de España, Madrid, Centro de Estudios Políticos y Constitucionales.

Coll Coll, Ana María (2015), La intendencia de Mallorca en el siglo XVIII, Tesis Doctoral inédita, Universidad de Palma de Mallorca $<$ https://www.tesisenred. net/bitstream/handle/10803/382816/tamccldel.pdf? sequence $=1 \&$ isAllowed $=\mathrm{y}>$.

Corona, Carlos E. (1980), «Los “cuerpos” de Zaragoza según el marqués de Avilés, intendente de Zaragoza en 1766», Cuadernos de Historia Jerónimo Zurita, 37-38, pp. 99-116.

Coronas González, Santos M. (1992), Ilustración y derecho: los fiscales del Consejo de Castilla en el siglo XVIII, Madrid, Ministerio para las Administraciones Públicas.

Coronas González, Santos M. (1998), «La reforma judicial de Aranda (1766-1777)», Anuario de Historia del Derecho Español, 68, pp. 45-82.

Coronas González, Santos M. (2010), «La ley en la España del siglo XVIII», Anuario de Historia del Derecho Español, 80, pp. 183-242.

DEDIEU, Jean-Pierre (2011), «El aparato de gobierno de la Monarquía española en el siglo XVIII», en Pérez Sarrión, Guillermo (ed.), Más Estado y más mercado. Absolutismo y economía en la España del siglo XVIII, Madrid, Sílex, pp. 53-73.

DuBET, Anne (2011), «Los intendentes y la tentativa de reorganización del control financiero en España», en Pérez Sarrión, Guillermo (ed.), Más Estado y más mercado. Absolutismo y economía en la España del siglo XVIII, Madrid, Sílex, pp. 103-136.

DuBET, Anne (2016), «El marqués de la Ensenada y la vía reservada en el gobierno de la Hacienda americana: un proyecto de equipo», Estudios de Historia Novohispana, 55, pp. 99-116<https://doi.org/10.1016/j.ehn.2016.09.001>.

Estrada SÁnchez, Manuel (2003), «Auge y decadencia de los intendentes: una aproximación a los (fracasados) proyectos reformistas borbónicos en materia de organización territorial», Edades. Revista de Historia, 11, pp. 211-227.

FAYARD, Janine (1982), Los miembros del Consejo de Castilla (1621-1746), Madrid, Siglo XXI. 
Franch BenaVEnt, Ricardo (2002), «Las oportunidades del enriquecimiento ilícito generadas por el ejercicio de la intendencia más "tentadora" de España: la pesquisa realizada al marqués de Avilés como intendente de Valencia en 1762», Estudis. Revista de Historia Moderna, 28, pp. 263-285.

Franch BenaVent, Ricardo (2014), «Poder, negocio y conflictividad social: el reforzamiento de la autoridad del intendente en la Valencia del siglo XVIII», Espacio, tiempo y forma. Historia Moderna, 27, pp. 61-83<https://doi. org/10.5944/etfiv.27.2014.13701>.

Fernández Albaladejo, Pablo (1992), Fragmentos de monarquía, Madrid, Alianza Editorial.

FernáNDez Vega, Laura (1982), La Real Audiencia, órgano de gobierno (1480-1808), La Coruña, Diputación Provincial, 3 vols.

GARCÍA GARCíA, Carmen (1996), La crisis de las haciendas locales: de la reforma administrativa a la reforma fiscal (1743-1845), Valladolid, Junta de Castilla y León.

GARCÍA MONERRIS, Encarnación (1991), La monarquía absoluta y el municipio borbónico. La reorganización de la oligarquía urbana en el ayuntamiento de Valencia (1707-1800), Madrid, Consejo Superior de Investigaciones Científicas.

GARriga, Carlos (2002a), «Los límites del reformismo borbónico: a propósito de la administración de justicia en Indias», en Barrios, Feliciano (coord.), Derecho y administración pública en las Indias hispánicas, Cuenca, Universidad de Castilla-La Mancha, pp. 781-821.

GArriga, Carlos (2002b), «Gobierno», en Fernández Sebastián, Javier et Fuentes, Juan F. (eds.), Diccionario político y social del siglo XIX español, Madrid, Alianza Editorial, pp. 319-335.

GARriga, Carlos (2004), «Orden jurídico y poder político en el Antiguo Régimen», Istor, 16, pp. 13-44.

GARriga, Carlos (2006), «Sobre el gobierno de la justicia en Indias (siglos XVI-XVII)», Revista de Historia del Derecho, 34, pp. 67-160.

GARriga, Carlos (2007), «Justicia animada: Dispositivos de la justicia en la Monarquía católica», en Lorente, Marta (coord.), De justicia de jueces a justicia de leyes: hacia la España de 1870, Madrid, Consejo General del Poder Judicial, pp. 61-104.

GARriga, Carlos (2008), «La jurisdicción contencioso-administrativa en España. Una historia de sus orígenes», Cuadernos de Derecho Judicial, 7, pp. 45-113.

GARriga, Carlos (2010), «Sobre el gobierno de Cataluña bajo el régimen de la "Nueva Planta”. Ensayo historiográfico», Anuario de Historia del Derecho Español, 80, pp. 715-766. 
Gay EscoDA, José María (1988), «La culminación de las reformas de la administración municipal durante la Ilustración: el establecimiento de la carrera de corregimientos y varas y la "Instrucción de corregidores"», Documentación Jurídica, 15/60, pp. 107-194.

Giménez López, Enrique y Pradells Nadal, Jesús (1989), «Conflictos entre la Intendencia y la Capitanía General de Valencia durante el reinado de Felipe V. Las denuncias de corrupción», Studia historica. Historia Moderna, 7, pp. 592-596.

Gómez Gómez, Margarita (2004), «La nueva tramitación de los negocios en Indias en el siglo XVIII: de la "vía de Consejo" a la "vía reservada"», en Barrios, Feliciano (coord.), El gobierno de un mundo. Virreinatos y Audiencias en la América Hispánica, Cuenca, Universidad de Castilla-La Mancha, pp. 203-251.

Gómez Rivero, Ricardo (1999), El Ministerio de Justicia en España (1714-1812), Madrid, Centro de Estudios Políticos y Constitucionales.

Gómez URDÁÑEz, José Luis (1996), El proyecto reformista de Ensenada, Lleida, Editorial Milenio.

Gómez UrdáÑez, José Luis (2019), Fernando VIy la España discreta, Madrid, Punto de Vista Editores.

GonzÁlez Alonso, Benjamín (1970), El corregidor castellano (1348-1808), Madrid, Instituto de Estudios Administrativos.

GonzÁlez FuerTes, Manuel A. (2003), La organización institucional de la Cámara de Castilla en la época borbónica, Córdoba, Servicio de Publicaciones Universidad de Córdoba.

GonzÁlez Fuertes, Manuel A. (2010), «La reestructuración de la administración judicial en la Corona de Castilla (1700-1749)», en Dubet, Anne et Ruiz Ibáñez, José Javier (eds.), Las monarquías española y francesa (siglos XVI-XVIII) ¿Dos modelos políticos?, Madrid, Casa de Velázquez, pp. 111-129.

GONZÁLEZ FuERTES, Manuel A. (2019), «¿El hábito hace al monje? Institucionalización de la carrera judicial en España a finales del Antiguo Régimen», Studia historica, Historia moderna, 39/1, pp. 229-262 <https://doi.org/10.14201/ shhmo2017391229262>.

Granados Loureda, Juan Antonio (1986), Un ejemplo de comisariado en el Antiguo Régimen español. La Intendencia de Galicia, 1712-1775, Memoria de Licenciatura inédita, Universidade de Santiago de Compostela.

IвÁÑEZ Molina, Manuel (1986), «Una visión retrospectiva sobre las intendencias de 1718: la del marqués de Ustáriz en 1748», Cuadernos de Investigación Histórica, 10, pp. 153-164.

Kamen, Henry (1964), «El establecimiento de los intendentes en la administración española», Hispania, 24, pp. 368-395. 
LóPEz DíAz, María (2015), «Señorío eclesiástico y jurisdicción en la Corona de Castilla (siglos XVI-XVIII)», en Cancila, Rossella et Musi, Aurelio (a cura di), Feudalesimi nel Mediterraneo moderno, Palermo, Associazione Mediterranea (Quaderni Mediterranea. Ricerche storiche, 27), II, pp. 351-380.

LóPEz DíAz, María (2019), «Intendencia y justicia: una visión comparada de las ordenanzas de 1718 y 1749», Mediterranea. Ricerche storiche, 32, pp. 539-570 $<$ https://www.doi.org/10.19229/1828-230X/4772019>.

Molas Ribalta, Pere (2000), Los magistrados de la Ilustración, Madrid, Boletín Oficial del Estado - Centro de Estudios Políticos y Constitucionales.

MuÑoz RoDRÍGUEZ, Julio David (2010), «El superintendente austríaco y el intendente borbónico. La evolución de un modelo de gestión de los recursos fiscales de la monarquía», en Dubet, Anne et Ruiz Ibáñez, Juan J. (eds.), Las monarquías española y francesa (siglos XVI-XVIII) ¿Dos modelos políticos?, Madrid, Casa de Velázquez, 117, pp. 131-141.

PÉREZ MARTín, Jesús Gabriel (1987), Reformismo y administración provincial. La intendencia de Burgos en el siglo XVIII, Tesis de doctorado inédita, Universidad Autónoma de Madrid.

Peset Reig, Mariano (1972), «Notas sobre la evolución de los fueros de Valencia», Anuario de Historia del Derecho Español, 42, pp. 657-713.

SAAVEDRA VÁzQueZ, María del Carmen (2020), «El establecimiento de la Intendencia y sus efectos en la defensa de Galicia (1715-1719)», Obradoiro de historia moderna, 29 (en este mismo monográfico).

Vallejo García-Hevia, José María (1996-1997), «Reseña a Abbad, F. y Ozanam, D.: Les Intendants espagnols du XVIIIe siècle, Casa de Velázquez, Madrid, 1992; 258 págs.», Ius Fulgit. Revista interdiciplinar de estudios histórico-jurídicos, 5-6, pp. 547-557.

VAllejo García-Hevia, José María (2008), La Monarquía y un ministro, Campomanes, Madrid, Centro de Estudios Políticos y Constitucionales. 